\title{
EFFECT OF MANURES WITH FERTILIZERS ON YIELD AND YIELD TRAITS OF MUNGBEAN (Vigna radiata L.)
}

\author{
M. E. Hossain and M. S. Islam* \\ Department of Agronomy, Sher-e-Bangla Agricultural University, Dhaka-1207, Bangladesh \\ *Corresponding author, E-mail:
}

(Received: 14 December 2017, Accepted: 17 January 2018)

Keywords: BARI Mung-6, Vermicompost, 1000-Seed weight and seed yield.

\begin{abstract}
An experiment was carried out at the Agronomy Field of Sher-e-Bangla Agricultural University, Dhaka during the period from March to June 2015 (Kharif-I season) to find out the effect of different manures along with inorganic fertilizers on yield and yield traits of mungbean varieties. The experiment consisted of two factors: factor A: five levels of manures along with inorganic fertilizers [ $\mathrm{T}_{0}=$ Control (no fertilizer or manure), $\mathrm{T}_{1}=$ Recommended dose of fertilizer $(\mathrm{R})\left(45 \mathrm{~kg}\right.$ urea ha ${ }^{-1}+100 \mathrm{~kg} \mathrm{TSP} \mathrm{ha}{ }^{-1}+58 \mathrm{~kg}$ MoP ha-1), $\mathrm{T}_{2}=\mathrm{R}+$ cowdung $\left(3 \mathrm{tha}^{-1}\right), \mathrm{T}_{3}=\mathrm{R}+$ poultry manure $\left(2 \mathrm{t} \mathrm{ha} \mathrm{a}^{-1}\right), \mathrm{T}_{4}=\mathrm{R}+$ vermicompost (2.5 t ha-1)] and factor $B$ : two mungbean varieties; $\left(V_{1}=\right.$ BARI Mung 5 and $\mathrm{V}_{2}=\mathrm{BARI}$ Mung 6 ). The experiment was laid out in split- plot design with three replications. The effect of manures along with recommended inorganic fertilizers on yield and yield traits were found significant. The maximum grain yield (1.53 tha $\left.{ }^{-1}\right)$ and maximum stover yield (1.88 $\mathrm{t} \mathrm{ha}^{-1}$ ) was recorded from $\mathrm{T}_{4}$ treatment. Mungbean variety had also significant influence on yield and yield traits. The maximum seed yield $(1.58 \mathrm{t}$ $\mathrm{ha}^{-1}$ ) was obtained from var. BARI Mung 6) but Maximum stover yield (1.91 t ha-1) was obtained from var. BARI Mung 5). The combined effects of manures along with recommended inorganic fertilizers and variety were found statically significant on yield and yield traits. The maximum seed yield $\left(2.01 \mathrm{t} \mathrm{ha}^{-1}\right)$ and maximum stover yield (2.61 $\mathrm{t} \mathrm{ha}{ }^{-1}$ ) was recorded from $\mathrm{T}_{4} \mathrm{~V}_{2}$. There were positive correlations of seed yield with different yield components. It was comparatively stronger correlations in BARI Mung 5 and weaker in BARI Mung 6. So, var. BARI Mung 6 performed the best result with the application of vermi-compost @ $2.5 \mathrm{t} \mathrm{ha}^{-1}$ with recommended dose of fertilizer.
\end{abstract}

\section{Introduction}

Mungbean (Vigna radiata L.) is an important short duration, drought tolerant pulse crop which is also commonly known as "green gram". It has an edge over other pulses because of its high nutritive value, digestibility and non-flatulent behavior. Average yield of mungbean in Bangladesh is very low, which is primarily due to lack of proper methods of cultivation, poor crop stand, imbalanced fertilization, poor plant protection measures and lack of high yielding varieties. The low yield of mungbean besides other factors may partially be due to lack of knowledge about nutrition and modern production technology (Hassan, 1997).

Moreover, lack of attention on fertilizer use is also hampered the lowering of mungbean yields (Mansoor, 2007). Variety plays an important role in producing high yield of mungbean because different varieties responded differently for their genotypic characters. Very recently, with the introduction of some high yielding varieties viz., BARI Mung- 6 and BARI Mung- 5 increasing attention is being paid to the cultivation of this crop in order to mitigate the alarmingly protein shortage in the diet of our people. Mungbean is highly responsive to fertilizers and manures. It 
has a marked response to nitrogen $(\mathrm{N})$, phosphorus $(\mathrm{P})$ and potassium $(\mathrm{K})$. These nutrients play a key role in plant physiological process. Cowdung has relatively less $\mathrm{N}$ than some other manure, so it can be added directly to the soil without damaging plants. Poultry manure is an excellent source of organic fertilizer which is rich in micro and macronutrients. Poultry manure also improves nutrient status in soil and at the same time may reduce soil pollution, which developed from the continuous use of chemical fertilizer. Vermi-composting is the processing of organic wastes with earthworms. During this process, elements like N, P, K, and Ca present in the waste are released and converted, through microbial activity, into forms more soluble and available to plants than those present in the original waste (Edwards and Burrows, 1988). Phosphorus plays a remarkable role in plant physiological processes. It is an essential constituent of majority of enzymes which are of great importance in the transformation of energy in carbohydrate metabolism in different types of plants and is closely related in cell division and seed development. Potassium, as a plant nutrient, is becoming increasingly important in Bangladesh and a good crop response to $\mathrm{K}$ is being reported from many parts of the country. Pulse crops showed yield benefits from $\mathrm{K}$ application and also improved $\mathrm{K}$ supply enhances biological N fixation and protein content of pulse seed (Srinivasarao et al., 2003). Considering the above facts, the present investigation aimed to find out the optimum doses of manures and inorganic fertilizers for maximizing the yield and yield contributing characters of two selected mungbean varieties.

\section{Materials and Methods}

The experiment was carried out at the Agronomy field of Sher-e-Bangla Agricultural University (SAU), Dhaka. The experimental site is situated at $23^{\circ} 77^{\prime}$ North Latitude and $90^{\circ} 30^{\prime}$ East Longitude. The elevation of the experimental site is $8.0 \mathrm{~m}$ above the sea level. The area belongs to the Agro-ecological Zone -28: (Madhupur Tract). Mungbean var. BARI mung-5 $\left(\mathrm{V}_{1}\right)$ and BARI mung- $6\left(\mathrm{~V}_{2}\right)$ were used in the study. The experiment was laid out in split- plot design with three replications. The experiment consisted of two factors: factor $\mathrm{A}$ : five levels of manures and inorganic fertilizers; $\left[T_{0}=\right.$ Control (no fertilizer or manure) $T_{1}=$ Recommended dose of fertilizer (R) (45 kg urea ha-1 $\left.+100 \mathrm{~kg} \mathrm{TSP} \mathrm{ha-1}+58 \mathrm{~kg} \mathrm{MoP} \mathrm{ha}^{-1}\right), \mathrm{T}_{2}=\mathrm{R}+$ cowdung $\left(3 \mathrm{t} \mathrm{ha}^{-1}\right), \mathrm{T}_{3}=\mathrm{R}+$ poultry manure $\left(2 \mathrm{t} \mathrm{ha}^{-1}\right), \mathrm{T}_{4}=\mathrm{R}+$ vermi-compost $\left.\left(2.5 \mathrm{t} \mathrm{ha}^{-1}\right)\right]$ and factor B: two mungbean varieties; $\left(V_{1}=\right.$ BARI Mung 5 and $V_{2}=$ BARI Mung 6).

The experimental land was opened with a power tiller and subsequently ploughed twice followed by laddering. Weeds, stubbles and crop residues were removed. Except urea, all manures (cowdung, poultry manure and vermi-compost) were applied along with TSP, MoP, gypsum, zinc sulphate and boric acid as per treatments during the final land preparation. The urea was applied at two intervals. First half was applied during final land preparation and rest was applied at 25 DAS followed by light irrigation. Mungbean seeds were sown on 01 March, 2015 . Healthy seeds of mungbean @ $35 \mathrm{~kg} \mathrm{ha}^{-1}$ were sown by hand as uniformly as possible in furrows. Seeds were sown in the afternoon and immediately covered with soil to avoid sunlight. Line to line distance was maintained $30 \mathrm{~cm}$. Gap filling, weeding, application of irrigation water and plant protection measures were taken properly when needed. Data on number of pods plant $^{-1}$, pods length $(\mathrm{cm})$, number of seeds pod ${ }^{-1}, 1000$-grain weight, seed yield ( $\left.\mathrm{t} \mathrm{ha}^{-1}\right)$, stover yield $\left(\mathrm{t} \mathrm{ha} \mathrm{a}^{-1}\right)$, biological yield $\left(\mathrm{t} \mathrm{ha} \mathrm{a}^{-1}\right)$ and harvest index (\%) were recorded and were statistically analyzed following the analysis of variance by using MSTAT-C computer package program and the treatment means were compared by Least Significant Difference (LSD) test at 5\% level of probability. 


\section{Results and Discussion}

\section{Effect of manures along with recommended inorganic fertilizers}

The effect of manures along with recommended inorganic fertilizers on number of pods plant ${ }^{-1}$, pod length, number of seeds pod ${ }^{-1}$ and 1000- seed weight were found significant (Table 1). The maximum pods plant ${ }^{-1}(12.65)$, pod length $(9.36 \mathrm{~cm})$, seeds pod ${ }^{-1}(9.61)$ and 1000 - seed weight $(37.19 \mathrm{~g})$ were found in $\mathrm{T}_{4}$ [Recommended dose of fertilizer + vermicompost $(2.5 \mathrm{t}$ ha $^{-1}$ )], which were statistically similar to $T_{3}$ (regarding pods plant ${ }^{-1}$ ), $T_{3}$ and $T_{2}$ (regarding pod length and 1000- seed weight) and, $T_{3}, T_{2}$ and $T_{1}$ (regarding seeds pod ${ }^{-1}$ ). The lowest pods plant $^{-1}(9.83)$, pod length $(8.08 \mathrm{~cm})$, seeds pod $^{-1}(8.17)$ and 1000 - seed weight $(34.32 \mathrm{~g})$ were found in Control, which were statistically similar to $T_{1}$ and $T_{2}$ (regarding pods plant ${ }^{-1}$ ) and $T_{1}$ (regarding pod length and 1000- seed weight) whereas significantly different from all other treatments (regarding seeds pod $^{-1}$ ) (Table 1). With the increasing rate of vermi-compost, increased number of pods plant ${ }^{-1}$ were also observed by Ashraf et al. (2003), Aruna and Narsa (1999), Mastan et al. (1999), Kalita (1989) and Reddy et al. (1990); number of seeds pod ${ }^{-1}$ and 1000-seed weight by Channaveerswami (2005), Rajkhowa et al. (2002), Chinnamuthu and Venkatakrishnan (2001) and Patil (1998). Yields and harvest index of mungbean were also significantly influenced by manures along with recommended inorganic fertilizers (Table 1). The treatment $\mathrm{T}_{4}$ (Recommended dose of fertilizer + vermicompost $2.5 \mathrm{t} \mathrm{ha}^{-1}$ ) produced the maximum stover yield $\left(1.88 \mathrm{t} \mathrm{ha}^{-1}\right)$, seed yield $\left(1.53 \mathrm{t} \mathrm{ha}^{-1}\right)$, biological yield $\left(3.41 \mathrm{t} \mathrm{ha} \mathrm{h}^{-1}\right)$ and harvest index (44.86\%), which were statistically similar to $T_{3}$ for stover yield $\left(1,87 \mathrm{t} \mathrm{ha}^{-1}\right)$, seed yield (1.46 t ha-1) and biological yield $\left(3.33 \mathrm{t} \mathrm{ha}^{-1}\right)$ whereas significantly different from all the other treatments for harvest index. The control treatment produced the lowest stover yield $\left(1.46 \mathrm{t} \mathrm{ha}^{-1}\right)$, seed yield $\left(1,04 \mathrm{t} \mathrm{ha}^{-1}\right)$, biological yield $\left(2.50 \mathrm{t} \mathrm{ha}^{-1}\right)$ and harvest index $(41.61 \%)$. The values regarding these parameters recorded from $T_{1}$ and $T_{2}$ were statistically similar (Table 4). Similar results were also reported by Oad and Buriro (2005) in mungbean, Roy and Singh (2006) in malt barley and Aruna and Narsa (1999) in soybean regarding seed yield. The positive effect of vermi-compost along with recommended inorganic fertilizers might be due to their ability to improve soil physical properties, which provide favourable soil health and conditions and thereby increased the yield contributing parameters and yield.

Table 1. Effect of manures along with recommended inorganic fertilizers on yield attributes, yield and harvest index of mungbean

\begin{tabular}{ccccccccc}
\hline Treatment & $\begin{array}{c}\text { Pods } \\
\text { plant }{ }^{-1} \\
(\mathrm{no})\end{array}$ & $\begin{array}{c}\text { Pod } \\
\text { length } \\
(\mathrm{cm})\end{array}$ & $\begin{array}{c}\text { Seeds } \\
\text { pod }^{-1} \\
\left(\text { no. }^{-}\right)\end{array}$ & $\begin{array}{c}1000- \\
\text { seed } \\
\text { weight }(\mathrm{g})\end{array}$ & $\begin{array}{c}\text { Seed } \\
\text { yield } \\
\left(\mathrm{t} \mathrm{ha}^{-1}\right)\end{array}$ & $\begin{array}{c}\text { Stover } \\
\text { yield } \\
\left(\mathrm{t} \mathrm{ha}^{-1}\right)\end{array}$ & $\begin{array}{c}\text { Biological } \\
\text { yield } \\
\left(\mathrm{t} \mathrm{ha}^{-1}\right)\end{array}$ & $\begin{array}{c}\text { Harvest } \\
\text { Index (\%) }\end{array}$ \\
\hline $\mathrm{T}_{0}$ & $9.83 \mathrm{~b}$ & $8.08 \mathrm{~b}$ & $8.17 \mathrm{~b}$ & $34.32 \mathrm{~b}$ & $1.04 \mathrm{c}$ & $1.46 \mathrm{c}$ & $2.50 \mathrm{c}$ & $41.60 \mathrm{~d}$ \\
$\mathrm{~T}_{1}$ & $10.68 \mathrm{~b}$ & $8.43 \mathrm{~b}$ & $8.88 \mathrm{a}$ & $35.28 \mathrm{~b}$ & $1.27 \mathrm{~b}$ & $1.60 \mathrm{~b}$ & $2.87 \mathrm{~b}$ & $44.25 \mathrm{~b}$ \\
$\mathrm{~T}_{2}$ & $10.74 \mathrm{~b}$ & $8.91 \mathrm{a}$ & $9.34 \mathrm{a}$ & $35.77 \mathrm{a}$ & $1.30 \mathrm{~b}$ & $1.65 \mathrm{~b}$ & $2.95 \mathrm{~b}$ & $44.06 \mathrm{~b}$ \\
$\mathrm{~T}_{3}$ & $12.01 \mathrm{a}$ & $9.03 \mathrm{a}$ & $9.15 \mathrm{a}$ & $35.90 \mathrm{a}$ & $1.46 \mathrm{a}$ & $1.87 \mathrm{a}$ & $3.33 \mathrm{a}$ & $43.84 \mathrm{c}$ \\
$\mathrm{T}_{4}$ & $12.65 \mathrm{a}$ & $9.36 \mathrm{a}$ & $9.61 \mathrm{a}$ & $37.19 \mathrm{a}$ & $1.53 \mathrm{a}$ & $1.88 \mathrm{a}$ & $3.41 \mathrm{a}$ & $44.86 \mathrm{a}$ \\
\hline $\mathrm{LSD}_{(0.05)}$ & 1.74 & 0.79 & 0.94 & 1.84 & 0.22 & 0.27 & 0.33 & 0.46 \\
$\mathrm{CV}(\%)$ & 13.05 & 9.47 & 10.12 & 15.71 & 7.21 & 11.58 & 8.75 & 3.81 \\
\hline
\end{tabular}

In a column, means with same letter (s) are not significantly different by LSD at $5 \%$ level of significance

$\mathrm{T}_{0}$ : Control (no fertilizer or manure), $\mathrm{T}_{1}$ : Recommended dose of fertilizer (45 kg urea ha ${ }^{-1}+100 \mathrm{~kg}$ TSP $\mathrm{ha}^{-1}+58 \mathrm{~kg}$ MoP ha $\left.{ }^{-1}\right), \mathrm{T}_{2}$ : Recommended dose of fertilizer + cowdung (3 $\left.\mathrm{tha}^{-1}\right), \mathrm{T}_{3}$ : Recommended dose of fertilizer + poultry manure $\left(2 \mathrm{t} \mathrm{ha}^{-1}\right)$, and $\mathrm{T}_{4}$ : Recommended dose of fertilizer + vermi-compost $\left(2.5 \mathrm{t} \mathrm{ha}^{-1}\right)$ 


\section{Effect of variety}

Mungbean variety had significant influence on number of pods plant ${ }^{-1}$, pod length, seeds pod ${ }^{-1}$, 1000 -seed weight and stover yield, seed yield, harvest index (Table 2). The var. BARI Mung 6 produced higher pods plant ${ }^{-1}(11.80)$, pod length $(8.64 \mathrm{~cm})$, seeds pod ${ }^{-1}(9.18), 1000$ - seed weight $(36.30 \mathrm{~g})$, seed yield $\left(1.58 \mathrm{t} \mathrm{ha}^{-1}\right)$ and harvest index (52.14\%) whereas lower stover yield (1.45 t ha ${ }^{-1}$ ) compared to var. BARI Mung 5 of which values for corresponding parameters were 10.41, $7.65 \mathrm{~cm}, 8.16,35.07,1.29 \mathrm{t} \mathrm{ha}^{-1}, 40.31 \%$ and $1.91 \mathrm{t} \mathrm{ha}^{-1}$, respectively. The var. BARI Mung $5\left(3.20 \mathrm{t} \mathrm{ha}^{-1}\right)$ and BARI Mung $6\left(3.03 \mathrm{t} \mathrm{ha}^{-1}\right)$ was produced the statistically similar biological yield (Table 3).

Table 2. Effect of variety on yield attributes, yield and harvest index of mungbean

\begin{tabular}{ccccccccc}
\hline Treatment & $\begin{array}{c}\text { Pods } \\
\text { plant }^{-1} \\
(\text { no. })\end{array}$ & $\begin{array}{c}\text { Pod } \\
\text { length } \\
(\mathrm{cm})\end{array}$ & $\begin{array}{c}\text { Seeds } \\
\text { pod }^{-1} \\
(\mathrm{no} .)\end{array}$ & $\begin{array}{c}1000- \\
\text { seed } \\
\text { weight } \\
(\mathrm{g})\end{array}$ & $\begin{array}{c}\text { Seed } \\
\text { yield } \\
\left(\mathrm{t} \mathrm{ha}^{-1}\right)\end{array}$ & $\begin{array}{c}\text { Stover } \\
\text { yield } \\
\left(\mathrm{t} \mathrm{ha}^{-1}\right)\end{array}$ & $\begin{array}{c}\text { Biological } \\
\text { yield } \\
\left(\mathrm{t} \mathrm{ha}^{-1}\right)\end{array}$ & $\begin{array}{c}\text { Harvest } \\
\text { Index (\%) }\end{array}$ \\
\hline $\mathrm{V}_{1}$ & $10.41 \mathrm{~b}$ & $7.65 \mathrm{~b}$ & $8.16 \mathrm{~b}$ & $35.07 \mathrm{~b}$ & $1.29 \mathrm{~b}$ & $1.91 \mathrm{a}$ & $3.20 \mathrm{a}$ & $40.31 \mathrm{~b}$ \\
$\mathrm{~V}_{2}$ & $11.80 \mathrm{a}$ & $8.64 \mathrm{a}$ & $9.18 \mathrm{a}$ & $36.30 \mathrm{a}$ & $1.58 \mathrm{a}$ & $1.45 \mathrm{~b}$ & $3.03 \mathrm{a}$ & $52.14 \mathrm{a}$ \\
\hline $\mathrm{LSD}(0.05)$ & 1.10 & 0.50 & 0.59 & 1.16 & 0.14 & 0.16 & $\mathrm{NS}$ & 3.37 \\
$\mathrm{CV}(\%)$ & 12.39 & 7.54 & 8.45 & 16.58 & 12.79 & 12.75 & 8.46 & 4.04 \\
\hline
\end{tabular}

In a column, means with same letter (s) are not significantly different by LSD at $5 \%$ level of significance

$\mathrm{V}_{1}$ : BARI Mung $5, \mathrm{~V}_{2}$ : BARI Mung 6

\section{Combined effect of manures along with recommended inorganic fertilizers and variety}

The combined effects of manures along with recommended inorganic fertilizers and variety were found significant on pods plant ${ }^{-1}$, pod length, seeds pod ${ }^{-1}, 1000$ - seed weight and stover yield, seed yield, biological yield and harvest index (Table 3). Combination of $\mathrm{T}_{2} \mathrm{~V}_{2}$ (combination of recommended dose of fertilizer + cowdung @3 tha ${ }^{-1}$ and BARI mung 6) produced the maximum pod length $(9.50 \mathrm{~cm})$, seeds pod $^{-1}(10.23), 1000$ - seed weight $(38.55$ g) and were statistically identical to that of $T_{3} V_{1}, T_{4} V_{1}, T_{0} V_{2}, T_{1} V_{2}, T_{3} V_{2}$ and $T_{4} V_{2}$ for pod length; that of $T_{1} V_{1}, T_{2} V_{1}, T_{4} V_{1}, T_{0} V_{2}, T_{3} V_{2}, T_{4} V_{2}$ for seeds pod ${ }^{-1}$ and that of $T_{3} V_{1}, T_{4} V_{1}$ and $\mathrm{T}_{4} \mathrm{~V}_{2}$ for 1000- seed weight.

Whereas, the lowest values these parameters were found in $T_{0} V_{1}$ (combination of no fertilizers and BARI mung 5) and were statistically similar to that of $T_{0} V_{2}, T_{1} V_{2}$ and $T_{2} V_{2}$ for pods plant ${ }^{-1}$, that of all the combinations except $T_{2} V_{2}, T_{3} V_{2}$ and $T_{4} V_{2}$ for seeds pod ${ }^{-1}$ and except $\mathrm{T}_{2} \mathrm{~V}_{2}$ for 100- seed weight. On the other hand, the combination of $\mathrm{T}_{4} \mathrm{~V}_{2}$ (combination of recommended dose of fertilizer + vermicompost @ $2.5 \mathrm{t} \mathrm{ha}^{-1}$ and BARI mung 6) produced the highest pods plant ${ }^{-1}$ (12.78), stover yield $\left(2.61 \mathrm{t} \mathrm{ha}^{-1}\right)$, seed yield $\left(2.01 \mathrm{t} \mathrm{ha}^{-1}\right)$ and biological yield $\left(4.62 \mathrm{t} \mathrm{ha}^{-1}\right)$ and were statically identical to all other treatment combinations except $\mathrm{T}_{0} \mathrm{~V}_{1}$ for pods plant ${ }^{-1}$, significantly different from all other treatment combinations for stover yield and biological yield and except $\mathrm{T}_{4} \mathrm{~V}_{1}$ for seed yield. The combination of $\mathrm{T}_{1} \mathrm{~V}_{2}$ (Combination of no fertilizers with BARI mung 6) produced the highest harvest index (56.83\%) and was significantly different from that of all other combinations. The combination of $\mathrm{T}_{0} \mathrm{~V}_{1}$ produced the lowest values for these parameters (Table 3). These results are also inconformity with the findings of Channaveerswami (2005), Patil (1998), Abbas et al. (2011), Rajkhowa et al. (2002), Chinnamuthu and Venkatakrishnan (2001), Kumar et al. (2002). 
Effect of Manures with Fertilizers on Yield and Yield Traits of Mungbean

Table 3. Combined effect of manures along with recommended inorganic fertilizers and variety on yield attributes, yields and harvest index of mungbean

\begin{tabular}{ccccccccc}
\hline $\begin{array}{c}\text { Treat- } \\
\text { ment }\end{array}$ & $\begin{array}{c}\text { Pods } \\
\text { plant }{ }^{-1} \\
\text { (no.) }\end{array}$ & $\begin{array}{c}\text { Pod } \\
\text { length } \\
(\mathrm{cm})\end{array}$ & $\begin{array}{c}\text { Seeds } \\
\text { pod }^{-1} \\
(\text { no. })\end{array}$ & $\begin{array}{c}1000- \\
\text { seed } \\
\text { weight }(\mathrm{g})\end{array}$ & $\begin{array}{c}\text { Seed } \\
\text { yield } \\
\left(\mathrm{t} \mathrm{ha}^{-1}\right)\end{array}$ & $\begin{array}{c}\text { Stover } \\
\text { yield } \\
\left(\mathrm{t} \mathrm{ha}^{-1}\right)\end{array}$ & $\begin{array}{c}\text { Biological } \\
\text { yield } \\
\left(\mathrm{t} \mathrm{ha}^{-1}\right)\end{array}$ & $\begin{array}{c}\text { Harvest } \\
\text { Index (\%) }\end{array}$ \\
\hline $\mathrm{T}_{0} \mathrm{~V}_{1}$ & $9.19 \mathrm{~b}$ & $7.93 \mathrm{~b}$ & $8.01 \mathrm{c}$ & $35.08 \mathrm{~b}$ & $1.05 \mathrm{~d}$ & $1.23 \mathrm{~d}$ & $2.28 \mathrm{e}$ & $46.05 \mathrm{c}-\mathrm{e}$ \\
$\mathrm{T}_{1} \mathrm{~V}_{1}$ & $11.66 \mathrm{a}$ & $7.96 \mathrm{~b}$ & $9.15 \mathrm{a}-\mathrm{c}$ & $35.76 \mathrm{~b}$ & $1.17 \mathrm{~d}$ & $1.78 \mathrm{bc}$ & $2.95 \mathrm{~b}$ & $39.66 \mathrm{~g}$ \\
$\mathrm{~T}_{2} \mathrm{~V}_{1}$ & $12.35 \mathrm{a}$ & $8.00 \mathrm{~b}$ & $8.99 \mathrm{a}-\mathrm{c}$ & $35.83 \mathrm{~b}$ & $1.34 \mathrm{~cd}$ & $1.77 \mathrm{bc}$ & $3.11 \mathrm{~cd}$ & $43.09 \mathrm{f}$ \\
$\mathrm{T}_{3} \mathrm{~V}_{1}$ & $12.34 \mathrm{a}$ & $8.93 \mathrm{ab}$ & $8.60 \mathrm{bc}$ & $36.50 \mathrm{ab}$ & $1.29 \mathrm{~cd}$ & $1.49 \mathrm{~cd}$ & $2.78 \mathrm{de}$ & $46.41 \mathrm{c}-\mathrm{e}$ \\
$\mathrm{T}_{4} \mathrm{~V}_{1}$ & $12.31 \mathrm{a}$ & $8.81 \mathrm{ab}$ & $9.32 \mathrm{a}-\mathrm{c}$ & $36.67 \mathrm{ab}$ & $1.74 \mathrm{ab}$ & $2.13 \mathrm{~b}$ & $3.87 \mathrm{~b}$ & $44.96 \mathrm{~d}-\mathrm{f}$ \\
$\mathrm{T}_{0} \mathrm{~V}_{2}$ & $10.46 \mathrm{ab}$ & $8.73 \mathrm{ab}$ & $8.99 \mathrm{a}-\mathrm{c}$ & $35.59 \mathrm{~b}$ & $1.17 \mathrm{~d}$ & $1.25 \mathrm{~d}$ & $2.42 \mathrm{e}$ & $48.35 \mathrm{bc}$ \\
$\mathrm{T}_{1} \mathrm{~V}_{2}$ & $11.33 \mathrm{ab}$ & $8.56 \mathrm{ab}$ & $8.61 \mathrm{bc}$ & $35.60 \mathrm{~b}$ & $1.54 \mathrm{bc}$ & $1.17 \mathrm{~d}$ & $2.71 \mathrm{de}$ & $56.83 \mathrm{a}$ \\
$\mathrm{T}_{2} \mathrm{~V}_{2}$ & $11.05 \mathrm{ab}$ & $9.50 \mathrm{a}$ & $10.23 \mathrm{a}$ & $38.55 \mathrm{a}$ & $1.61 \mathrm{bc}$ & $1.77 \mathrm{bc}$ & $3.38 \mathrm{c}$ & $47.63 \mathrm{~b}-\mathrm{d}$ \\
$\mathrm{T}_{3} \mathrm{~V}_{2}$ & $12.53 \mathrm{a}$ & $9.03 \mathrm{ab}$ & $9.74 \mathrm{ab}$ & $35.31 \mathrm{~b}$ & $1.65 \mathrm{bc}$ & $1.61 \mathrm{c}$ & $3.26 \mathrm{c}$ & $50.61 \mathrm{~b}$ \\
$\mathrm{~T}_{4} \mathrm{~V}_{2}$ & $12.78 \mathrm{a}$ & $9.01 \mathrm{ab}$ & $10.08 \mathrm{a}$ & $36.96 \mathrm{ab}$ & $2.01 \mathrm{a}$ & $2.61 \mathrm{a}$ & $4.62 \mathrm{a}$ & $43.51 \mathrm{ef}$ \\
\hline $\mathrm{LSD}(0.05)$ & 2.46 & 1.11 & 1.32 & 2.61 & 0.31 & 0.41 & 0.47 & 3.22 \\
$\mathrm{CV}(\%)$ & 12.39 & 7.54 & 8.45 & 16.58 & 12.79 & 12.75 & 8.46 & 4.04 \\
\hline
\end{tabular}

In a column, means with same letter (s) are not significantly different by LSD at $5 \%$ level of significance

$\mathrm{T}_{0}$ : Control (no fertilizer or manure), $\mathrm{T}_{1}$ : Recommended dose of fertilizer (45 kg urea ha-1 $+100 \mathrm{~kg}$ TSP $\mathrm{ha}^{-1}+58 \mathrm{~kg} \mathrm{MoP}$ ha- $\left.{ }^{-1}\right), \mathrm{T}_{2}$ : Recommended dose of fertilizer + cowdung $\left(3 \mathrm{t} \mathrm{ha}^{-1}\right), \mathrm{T}_{3}$ : Recommended dose of fertilizer + moultry manure $\left(2 \mathrm{t} \mathrm{ha}^{-1}\right), \mathrm{T}_{4}$ : Recommended dose of fertilizer + vermicompost $(2.5 \mathrm{t}$ ha-1)

\section{Functional relationship between seed yield and different yield components}

There were positive correlations of seed yield with the different yield components. It was comparatively stronger in BARI Mung 5 and weaker in BARI Mung 6. The $\mathrm{R}^{2}$ value was found for pods plant ${ }^{-1}$ and seed yield in BARI Mung 5 was 0.7547 [Figure 1(a)] and BARI Mung 6 0.429 [Figure 1 (b)]; for seeds pod ${ }^{-1}$ and seed yield in BARI Mung 50.5078 [Figure 2(a)] and in BARI Mung 60.3967 [Figure 2 (b)], and for 1000- seed weight and seed yield in BARI Mung 50.6738 [Figure 3(a)] and in BARI Mung 60.1319 [Figure 3 (b)].

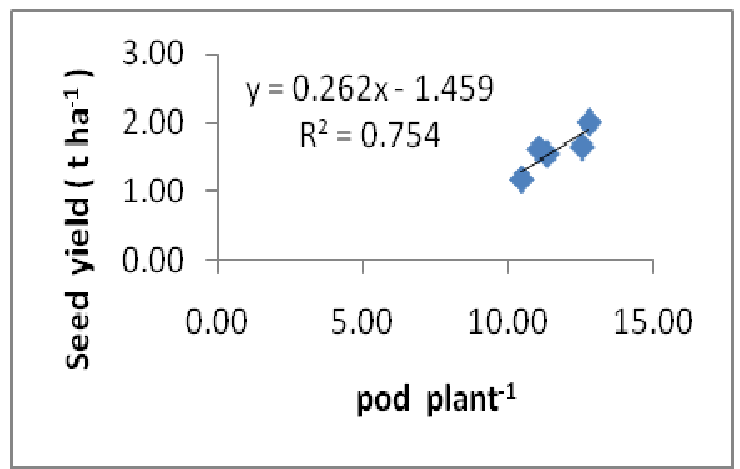

(a)

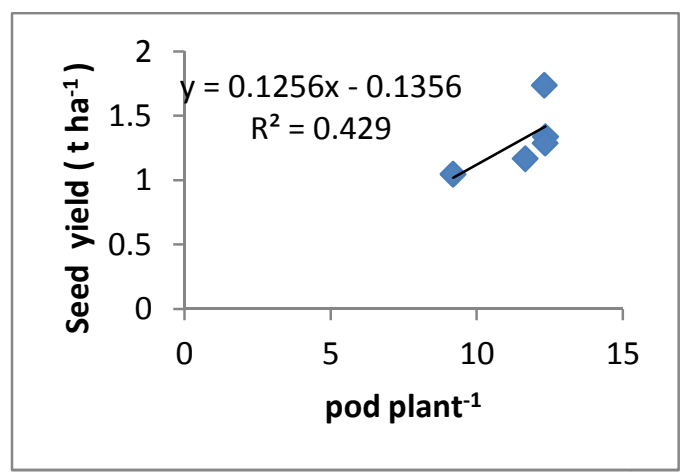

(b)

Fig. 1. Relationship between pod plant ${ }^{-1}$ and seed yield of BARI Mung 5 (a) and BARI Mung 6 (b) 


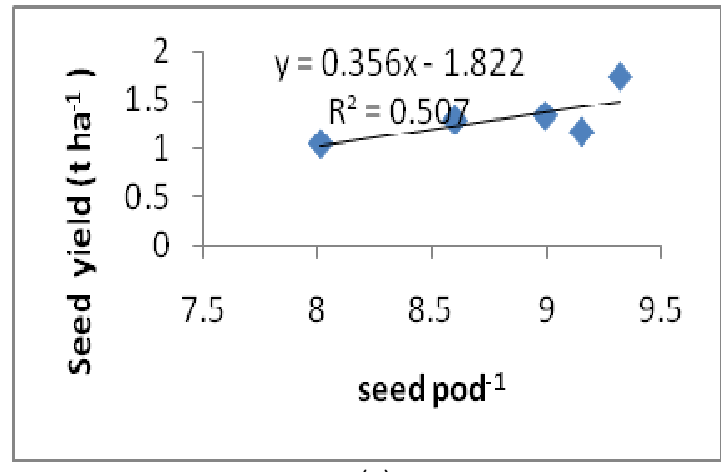

(a)

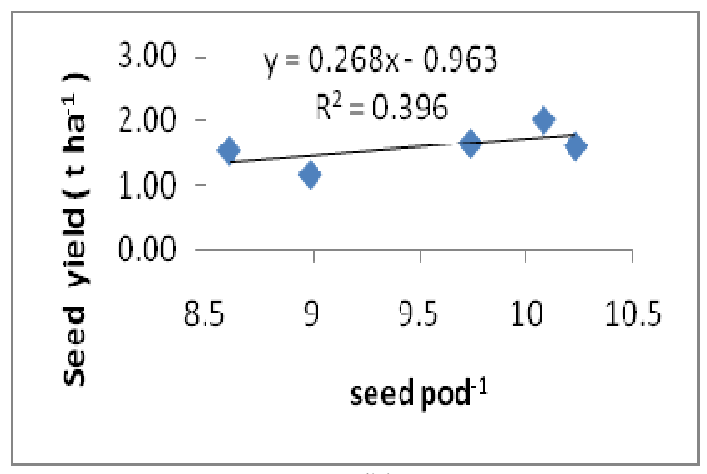

(b)

Fig. 2. Relationship between seed pod ${ }^{-1}$ and seed yield of BARI Mung 5 (a) and BARI Mung 6 (b)

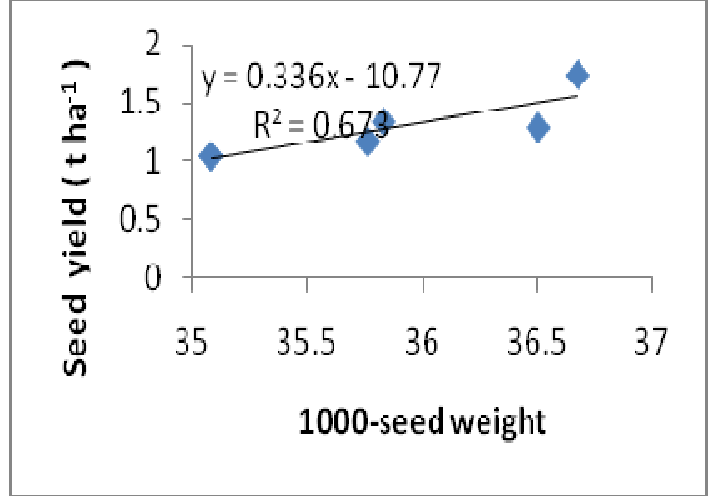

(a)

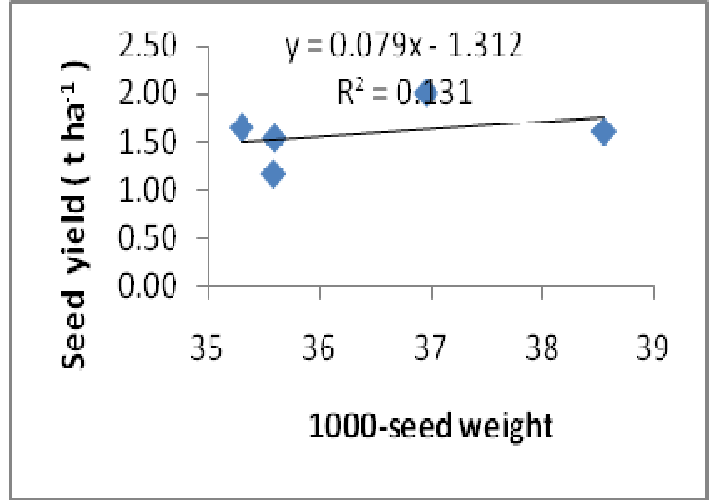

(b)

Fig. 3. Relationship between 1000-seed weight and seed yield of BARI Mung 5 (a) and BARI Mung 6 (b)

\section{Conclusion}

Based on the result of the present study it was found that mungbean var. BARI Mungbean 6 performed the highest seed yield $\left(2.01 \mathrm{t} \mathrm{ha}^{-1}\right)$ with the application of recommended dose of inorganic fertilizer ( $45 \mathrm{~kg}$ urea ha-1 $+100 \mathrm{~kg}$ TSP ha ${ }^{-1}+58 \mathrm{~kg} \mathrm{MoP} \mathrm{ha}^{-1}$ ) and vermi-compost at the rate of $2.5 \mathrm{t} \mathrm{ha}^{-1}$ for mungbean production in Kharif $-\mathrm{I}$ season. The cumulative effect of inorganic fertilizer ( $45 \mathrm{~kg}$ urea ha-1 $+100 \mathrm{~kg}^{-1 S P} \mathrm{ha}^{-1}+58 \mathrm{~kg} \mathrm{MoP} \mathrm{ha}^{-1}$ ) and vermi-compost at the rate of $2.5 \mathrm{t} \mathrm{ha}^{-1}$ performed the best result for var. BARI Mung 6 than BARI Mung 5 .

\section{Acknowledgement}

The authors are very much thankful to Ministry of Science and Technology, The People's Republic of Bangladesh, for NST fellowship during 2015-2016. 
Effect of Manures with Fertilizers on Yield and Yield Traits of Mungbean

\section{References}

Abbas, G., Aslam, M. Ullah, A. Malik, Z. Abbas, M. Ali and F. Hussain, 2011. Potassium sulfate effects on growth and yield of mungbean (Vigna radiata L.) Under arid climate. Int. J. Agric. Appl. Sci. 3 (2): 12-14

Aruna, P. and R. S. Narsa, 1999. Response of soybean (Glycine max) to conjunctive use of organic and inorganic sources of nitrogen. Indian J. Agric. Sci. 69 (5): $382-383$.

Ashraf, M., M. Mueen-Ud-Din and N. H. Warrick, 2003. Production efficiency of mungbean (Vigna radiata L.) as affected by seed inoculation and NPK application. Intl. J. Agric. Biol. 5(2): 179-180.

Channaveerswami, A. S. 2005. Studies on integrated nutrient management and planting methods on seed yield and quality of groundnut. Ph.D. Thesis, Univ. Agric. Sci., Dharwad, Karnataka (India).

Chinnamuthu, C. R. and Venkatakrishnan. 2001. Effect of integrating inorganic fertilizer with vermicompost and vescular arbuscular mycorrhizae (VAM) on the productivity of sunflower. Madras Agric. J. 88 (7-9): 424 - 427.

Edwards, C. A. and I. Burrows. 1988. The potential of earthworms composts as plant growth media. In: Edward, C.A. and Neuhauser, E.F. Eds., Earthworms in Waste and Environmental Management, SPB Academic Publishing, The Hague, 2132.

Hassan, R., 1997. Growth and yield response of mungbean to different seed rates and levels of phosphorus. M.Sc. Thesis, Agron. Dept., University of Agriculture Faisalabad, Pakistan.

Kalita, M. M. 1989. Effect of phosphorus and growth regulator on mungbean (Vigna radiata). Indian. J. Agron. 34 (2): 236-237.

Kumar, S., G. R. Choudhary and A. C. Chaudhari, 2002. Effects of nitrogen and biofertilizers on the yield and quality of coriander (Coriandrum sativum L.). Ann. Agr. Res. 23 (4): 634-637.

Mansoor, M. 2007. Evaluation of various agronomic management practices for increased productivity of Mungbean (Vigna radiata L. Wilszek). Ph.D thesis, Department of Agronomy, Faculty of Agriculture, Gomal University, D. I. Khan.

Mastan, S. C., S. N. Reddy, T. M. M. Reddy, M. Shaik and S. Mohammad, 1999. Productivity potential of rice-sunflower-mungbean cropping system as influenced by rational use of phosphorus. Indian. J. Agron. 44 (2): 232-236.

Oad, F. C. and U. A. Buriro, 2005. Influence of different NPK levels on the growth of mungbean. Crop Res. Hisar. 50: $40-42$.

Patil, B. S., 1998. Studies on integrated nutrient management in summer groundnut (Arachis hyphogea L.). M. Sc. (Agri). Thesis, Univ. Agric. Sci., Dharwad, Karnataka (India).

Rajkhowa, D. J., M. Saikia, and K. M. Rajkhowa, 2002. Effect of vermicompost with and without fertilizer on Greengram. Legume Res. 25 (4): 295-296.

Reddy, S. N., B. G. Singh and I. V. S. Rao, 1990. An analysis of dry matter production, growth and yield in mungbean and blackgram with phosphate fertilizer. J. M. Maharashtra Agril. Univ. 15 (2): 189-191. 
Roy, D. K. and Singh, 2006, Effect of level and time of nitrogen application with and without vermicompost on yield, yield attributes and quality of malt barley (Hordeum vulgare). Indian J. Agron. 51 (1): 40 - 42.

Srinivasarao, C., A. Masood, A. N. Ganeshamurthy and K. K. Singh. 2003. Potassium requirements of pulse crops. Better Crops Int. 17(1): $8-11$. 